\title{
Effect of luting space and cements on retention of implant supported crowns fabricated by laser sintering ${ }^{*}$
}

\author{
Özgün Yusuf Özyılmaz ${ }^{\alpha}$, Ceyda Akın ${ }^{\beta}$, Müjde Sevimay ${ }^{\gamma}$
}

Selcuk Dent J, 2017; 4: 10-16

Başvuru Tarihi: 31 Ocak 2017 Yayına Kabul Tarihi: 09 Şubat 2017

\section{ABSTRACT \\ Effect of luting space and cements on retention of implant supported crowns fabricated by laser sintering}

Background: The aim of this study was to evaluate the retention strength of five different cements used for implant supported crowns with two cement gap values.

Methods: Standard titanium abutments were scanned by means of a 3D digital laser scanner. 100 standard metal copings were designed by a CAD/CAM system with two cement gap values ( 20 and $40 \mu \mathrm{m}$ ). The copings were cemented to the abutments using the following five cements $(n=10)$. Poly F (PF), GC FujiCEM (GCF), Rely X (RX), MIS Crown Set(MCS) and Multilink $N$ (MN). The specimens were placed in $100 \%$ humudity for 24 hours then specimens were thermal cycled 1000 times. After thermal cycling specimens were subjected to a pull-out test using a universal testing machine at a $0.5 \mathrm{~mm} / \mathrm{min}$ crosshead speed. The test results were analyzed with two-way ANOVA, followed by multiple comparisons using Tamhane tests $(\alpha=0.05)$.

Results: Statistical analysis revealed that significant differences were observed among cement groups $(p<0.05)$. PF and MN had the highest and the least mean retentive strength, respectively. No significant difference was found between RX and MCS. Increasing the cement gap from 20 to $40 \mu \mathrm{m}$ improved retention significantly for each cement group $(p<0.05)$.

Conclusion: The ranking of cements presented in the study is meant to be an arbitrary guide for the clinician in deciding the appropriate cement selection for CAD/CAM fabricated metal copings onto implant abutments.

\section{KEYWORDS}

Cementation, cement gap, implant-supported prosthesis, retention

Dental implants have been used successfully for tooth replacement over the last few decades. Nevertheless, some controversy exists regarding the method for connecting the prosthesis to the implant. ${ }^{1-3}$ Implantsupported prostheses can be retained by screws or cement, depending primarily on the clinician's

\section{öz}

Lazer sinterize yoluyla üretilen implant destekli kronların tutuculuklarında siman aralığının ve simanların etkisi

Amaç: Bu çalıșmanın amacı iki farklı siman aralığı ile yapılan implant destekli kronlar için kullanılan beş farklı simanın tutuculuk mukavemetini değerlendirmektir.

Gereç ve Yöntemler: Standart titanyum dayanaklar dijital bir 3D lazer tarayıcı aracilığıyla tarandı. 100 standart metal alt yapı bir CAD/CAM sistem aracılığıyla iki farklı siman aralığı değerinde (20 ve $40 \mu \mathrm{m})$ tasarlandı. Alt yapılar beş farklı siman kullanılarak yapıştıııldı $(n=10)$. Poly $F(P F), G C$ FujiCEM (GCF), Rely X (RX), MIS Crown Set(MCS) and Multilink N (MN). Örnekler 24 saat bekletildikten sonra 1000 devir termal siklus uygulandı. Termal siklustan sonra örnekler universal test cihazında $0.5 \mathrm{~mm} / \mathrm{dk}$. hızla çekme testine tabi tutuldu. Test sonuçları iki yönlü varyans analizini takiben tamhane testleri kullanılarak çoklu karşıllaştırmalarla analiz edildi $(\alpha=0.05)$.

Bulgular: İstatistiksel analiz değerlendirildiğinde siman grupları arasında anlamlı farklııılar görüldü $(p<0.05)$. PF ve MN sırasıyla en yüksek ve en düşük tutuculuk kuvveti ortalamasına sahipti. RX ve MCS arasında anlamlı farklılık bulunmadı. 20 den $40 \mu \mathrm{m}$ ye artan siman aralığı, her siman grubu için tutuculuğu anlamlı ölçüde arttırdı $(p<0.05)$.

Sonuç: Çalışmada sunulan simanların klinisyenler için, implant dayanakların üzerine üretilen CAD/CAM metal alt yapılar için uygun siman seçimini belirlemede isteğe bağlı bir rehber olması amaçlanmıştır.

\section{ANAHTAR KELIMELER}

İmplant-destekli protez, siman, siman aralığı, tutuculuk

preference. $^{4-5}$ Although no consensus has been reached regarding the superiority of any method of retention, cement retention is more popular because of lower complication rates and higher fracture resistance of veneering ceramics.$^{6-11}$ It also offers the advantages of passive fit, improved

\footnotetext{
* Abstract presented at IADR, 10-13 September 2014. This paper has been edited to ensure that the language is clear and free of errors. The logical presentation of ideas and the structure of the paper were also checked during the editing process. The edit was performed by professional editors at Editage, a division of Cactus Communications

${ }^{\alpha}$ İstanbul Medipol Üniversitesi Diş Hekimliği Fakültesi Protetik Diş Tedavisi Anabilim Dall, İstanbul

$\beta$ Necmettin Erbakan Üniversitesi Diş Hekimliği Fakültesi Protetik Diş Tedavisi Anabilim Dalı, Konya

${ }^{\gamma}$ Selçuk Üniversitesi Diş Hekimliği Fakültesi Protetik Diş Tedavisi Anabilim Dalı, Konya
} 
esthetics, favorable occlusal surface by eliminating occlusal access openings, simplicity, and reduced cost. ${ }^{7,12,13}$ One disadvantage is that it may prevent removal of the prosthesis for maintenance. ${ }^{11,14}$

The ideal luting agent prevents loosening of the prosthesis during normal service. However, it allows removal without damage to the tissue interface, abutment, and restoration for replacement due to loosening or fracture of the fastening screw or fracture of the abutment, modification of the prosthesis after loss of the implant, and evaluation of oral hygiene and tissue

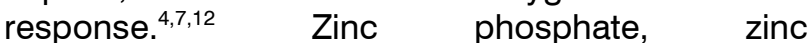
polycarboxylate, glass ionomer, and self-adhesive resin cements are preferred for permanent cementation of implant-supported restorations and frequently used as standards for studies of cement retention. ${ }^{15-17}$ However, the published studies on luting agents for such prostheses are inconclusive because of variability of experimental protocols and systems. ${ }^{4,13,15}$

The luting space reduces elevation of the restoration during cementation, improves outflow of excess cement, and lowers seating force, enhancing fit and retention of the prosthesis. ${ }^{18,19}$ It should be large enough to allow proper seating of the restoration without increasing the cement film thickness ${ }^{20}$; it should also be uniform. ${ }^{18}$ Grajower and Lewinstein ${ }^{21}$ stated that "optimum fit" of a casting can be achieved only if the relief space allows for the cement film thickness and roughness of the tooth and casting surfaces. They recommended a relief space of $50 \mu \mathrm{m}$ to be maintained on the die, including $30 \mu \mathrm{m}$ for the cement film and $20 \mu \mathrm{m}$ to compensate for distortion of the wax pattern. However, the development of computer-aided design and manufacturing (CAD/CAM) systems has largely eliminated distortions during fabrication. In recent years, most authors have reported that the ideal luting space ranges from 20 to $40 \mu \mathrm{m}^{22-26}$

Direct metal laser sintering (DMLS) is a promising technology to avoid distortions inherent to casting procedures. It involves the use of a high-power laser source, such as carbon dioxide laser, to fuse small particles of powdered alloy. Each dental structure is built in layers from the occlusal surface to the margins by scanning cross-sections in a three-dimensional CAD file of the framework designed after abutment digitization. ${ }^{27-30}$ Standard implant- and/or tooth-supported metal copings can be fabricated for passive fit by using an algorithm that ensures a uniform luting space..$^{31,32}$

\section{MATERIALS AND METHODS}

\section{Specimen preparation}

In this study, 100 standard titanium implant abutments with a diameter of $3.7 \mathrm{~mm}$ and height of $5 \mathrm{~mm}$ (Implant Direct Sybron International, Thousand Oaks, CA) and 100 standard implant analogs were used. The analogs were embedded in acrylic resin blocks (Meliodent, Bayer Dental, Newburg, Germany) with the aid of a surveyor. Each abutment was placed on its respective analog and torqued to $30 \mathrm{Ncm}$. One abutment was scanned by threedimensional digital laser in a dental CAD/CAM system (Dental Wings, Inc. Montreal, Canada). All copings were designed by DWOS Software (Dental Wings, Inc.) using the scanned data. The design included a luting space of either 20 or $40 \mu \mathrm{m}$ ( $n=50 /$ group), standardized coping thickness of $0.5 \mathrm{~mm}$, and a metal ring on the occlusal surface for pullout testing. The obtained files were transferred to a DMLS device (Concept Laser $\mathrm{GmbH}$, Lichtenfels, Germany).

For DMLS, the temperature of the device was gradually increased to $1650^{\circ} \mathrm{C}$. The process began by sintering a 20 $\mu \mathrm{m}$ layer of cobalt-chromium powder onto a stainless steel platform in an argon atmosphere. and then, 20- $\mu \mathrm{m}$ increments of the alloy powder were sintered from the bottom up until the copings were completed. The 500-W ytterbium-doped fiber laser was precisely controlled in the $x$ - and $y$-coordinates, maintaining exceptional tolerances $( \pm 0.0254)$. The copings were cooled to ambient temperature (decreasing at $9^{\circ} \mathrm{C} / \mathrm{min}$ ) inside the furnace. The internal surface of each coping was air-abraded with $50-\mu \mathrm{m}$ aluminum oxide particles.

Copings with different luting spaces were randomly selected, fitted to abutments, and examined under a light microscope (Olympus BX60, Olympus Optical Co. Ltd., Tokyo, Japan) at $\times 5$ magnification for proper fit. The internal surfaces of all the copings and abutment surfaces were steam-cleaned before cementation.

\section{Cementation, thermocycling, and pull-out testing}

The copings in each luting space group were randomly allocated to five equal cement subgroups ( $n=10 /$ subgroup) (Table 1): Poly $F$ (PF), GC FujiCEM (GCF), Rely X (RX), MIS Crown Set (MCS), and Multilink N (MN). All the cements were used according to the manufacturers' recommendations. The copings were seated with finger pressure and placed under a controlled axial load of $5 \mathrm{~kg}$ for $10 \mathrm{~min}$ at room temperature. Excess cement was removed with a curette. Thereafter, the specimens were stored in distilled water at $37^{\circ} \mathrm{C}$ for $24 \mathrm{~h}$. To simulate the oral environment, the specimens were subjected to 1000 cycles of thermocycling between $5^{\circ} \mathrm{C}$ and $55^{\circ} \mathrm{C}$, with a $30-\mathrm{s}$ dwell time before pullout testing. 
Table 1.

\section{Cements types and brands used in this investigation}

\begin{tabular}{|c|c|c|c|}
\hline Material & Type & Chemical Composition & Manufacturer \\
\hline $\begin{array}{l}\text { Rely X } \\
\text { U200 } \\
(\mathrm{RX})\end{array}$ & Self adhesive resin & $\begin{array}{l}\text { Base Paste: Methacrylate } \\
\text { monomers containing } \\
\text { phosphoric acid groups, } \\
\text { methacrylate monomers, } \\
\text { silanated fillers, initiator } \\
\text { components, stabilizers, } \\
\text { rheological additives Catalyst } \\
\text { paste: Methacrylate } \\
\text { monomers, alkaline (basic) } \\
\text { fillers, silanated fillers, initiator } \\
\text { components, } \\
\text { stabilizers,pigments, } \\
\text { rheological additives }\end{array}$ & $\begin{array}{c}\text { 3MESPE, } \\
\text { Deutschland,GmbH, } \\
\text { Germany }\end{array}$ \\
\hline $\begin{array}{l}\text { Multilink } \\
\mathrm{N}(\mathrm{MN})\end{array}$ & Self-etch resin & $\begin{array}{l}\text { Monomer matrix: } \\
\text { dimethacrylate and HEMA, } \\
\text { Inorganic fillers: barium } \\
\text { glass,ytterbium trifluoride, } \\
\text { spheroid mixed oxide }\end{array}$ & $\begin{array}{l}\text { Ivoclar Vivadent, } \\
\text { Schaan, } \\
\text { Liechtenstein }\end{array}$ \\
\hline $\begin{array}{l}\text { GC } \\
\text { FujiCEM } \\
\text { (GJF) }\end{array}$ & $\begin{array}{l}\text { Resin modified } \\
\text { glass ionomer } \\
\text { cement, self cured }\end{array}$ & $\begin{array}{c}\text { Paste A: fluoroaluminosilicate } \\
\text { glass, HEMA, dimethacrylate, } \\
\text { pigment, initiator } \\
\text { Paste B: Polyacrylic acid, } \\
\text { distilled water, silica powder, } \\
\text { initiator }\end{array}$ & $\begin{array}{l}\text { GC Dental Corp, } \\
\text { Tokyo, Japan }\end{array}$ \\
\hline $\begin{array}{l}\text { Poly F } \\
\text { (PF) }\end{array}$ & Zincpolycarboxylate & $\begin{array}{l}\text { Zinc oxide, magnesium } \\
\text { oxide, polyacrylic acid }\end{array}$ & $\begin{array}{c}\text { Dentsply,Wevbride, } \\
\text { UK }\end{array}$ \\
\hline $\begin{array}{l}\text { MIS } \\
\text { Crown } \\
\text { Set } \\
\text { (MCS) }\end{array}$ & Self cure resin & $\begin{array}{l}\text { Permanent cement for } \\
\text { implant-retained crowns }\end{array}$ & $\begin{array}{l}\text { Mis Imp Tech Ltd., } \\
\text { Osseous } \\
\text { Technologies of } \\
\text { America, } \\
\text { Huntington Beach, } \\
\text { CA }\end{array}$ \\
\hline
\end{tabular}

Pullout tests were performed with a universal testing machine (TSTM 02500, Elista Ltd. Şti., Istanbul, Turkey) at a $0.5-\mathrm{mm} / \mathrm{min}$ crosshead speed. The load required to fracture the cement was recorded in newtons, and mean values of each subgroup were calculated.

\section{Statistical analysis}

SPSS Statistics for Windows version 15.0.1 (SPSS, Inc., Chicago, IL) was used for all analyses. Data were compared by one- and two-way analysis of variance (ANOVA) followed by post hoc Tamhane's test. The significance level was set as $\mathrm{p}<0.05$.

\section{RESULTS}

Two-way ANOVA revealed a significant influence of the luting agent $(p<0.000)$ and luting space $(p<0.000)$ on retention of the copings. Their combined effect was also significant $(p<0.004)$ (Table 2).
Table 2.

Effect of cement type and cement gap on pull-out test results

\begin{tabular}{|lcc|}
\hline Source & F & Sig \\
\hline Cement & 3823,1 & 0 \\
\hline Cement Gap & 201,49 & 0 \\
\hline Cement ${ }^{\star}$ Cement Gap & 4,129 & 0,004 \\
\hline Two-way ANOVA test $(p<0.05)$ & \\
\hline
\end{tabular}

Table 3 summarizes the mean fracture loads and standard deviations. Significant differences were noted among the cement subgroups within each luting space group. In the $20-\mu \mathrm{m}$ group, the PF and MN subgroups had the highest and lowest mean fracture loads, respectively $(p<0.000)$. No significant difference was found between the RX and the MCS subgroups. The GCF subgroup $(p<0.003)$ showed superior values to all except the PF subgroup (Table 3 ).

\section{Table 3.}

\section{Means and standad deviations (SD) of forces required to decementation of the crowns}

\begin{tabular}{|c|c|c|c|}
\hline Cement & $20 \mu \mathrm{m}($ Mean \pm SD) & $40 \mu \mathrm{M}($ Mean \pm SD) & P (ANOVA) \\
\hline $\begin{array}{l}\text { Rely X } \\
\text { U200 }\end{array}$ & $211.53 \pm 7.19^{\mathrm{a}}$ & $241.74 \pm 11.99^{\mathrm{A}}$ & 0 \\
\hline $\begin{array}{l}\text { Multilink } \\
\mathrm{N}\end{array}$ & $168.67 \pm 13.80^{b}$ & $194.55 \pm 14.61^{B}$ & 0,032 \\
\hline $\begin{array}{l}\text { GC } \\
\text { FujiCEM }\end{array}$ & $431.10 \pm 18.54^{c}$ & $475.21 \pm 19.20^{C}$ & 0,003 \\
\hline Poly F & $597.06 \pm 12.74^{d}$ & $654.82 \pm 18.53^{D}$ & 0 \\
\hline $\begin{array}{l}\text { MIS } \\
\text { Crown } \\
\text { Set }\end{array}$ & $206.92 \pm 5.21^{\mathrm{a}}$ & $244.78 \pm 7.60^{\mathrm{A}}$ & 0 \\
\hline
\end{tabular}

*Different letters indicate statiscally significant difference $(p<0.05)$

Concerning the $40-\mu \mathrm{m}$ group, the PF subgroup showed significantly higher mean fracture load than the other subgroups $(p<0.000)$, whereas the MN subgroup had the lowest mean fracture load $(p<0.032)$. The GCF subgroup showed a significantly higher value than the $R X$ and MCS subgroups $(p<0.003)$, which were again not significantly different. Increase in the luting space from 20 to $40 \mu \mathrm{m}$ significantly increased the fracture load in every cement subgroup. 


\section{DISCUSSION}

In this study, the retentiveness of five luting agents for DMLS-fabricated copings with two luting spaces was evaluated by pullout tests. The failure mode was generally adhesive in nature and occurred at the cementabutment interface; residual cement was noted within most copings. The individual and combinatorial effects of the luting agent and luting space on retention were found to be significant, partly validating the hypothesis.

PF was the most retentive, as shown by Mansor. ${ }^{33}$ The reason for this finding is that polycarboxylate cements react with metal oxides of abutments and copings and form a chemical bond. ${ }^{34}$ Further, freeze-dried polycarboxylate acid chains in the powder component of $\mathrm{PF}$ are initiated by water addition. When the powder is surplus, the initiation reaction becomes so intense that large agglomerates of filler particles are formed and act as cotter bolts between the coping and the abutment. ${ }^{35}$

GCF was less retentive than PF. Resin-modified glass ionomer cements adhere to metal by chelating metallic ions, but retentiveness may be lowered by early water contact, resulting in matrix dissolution ${ }^{36,37} \mathrm{RX}$ and MCS yielded similar results; they can be classified as semipermanent cements and are recommended for common use, as they offer the simultaneous advantages of retrievability and adequate retentiveness. According to its manufacturer, MCS is a permanent cement for implantsupported restorations.

Although the bond strength of $\mathrm{MN}$ was considerably lower than the values of PF, GCF, RX, and MCS, the retentiveness of all the cements is adequate when a minimum tensile load of $200 \mathrm{~N}$ is used to determine clinical success ${ }^{38}$ Differences in the application method may have influenced the results: resin cements are highly technique sensitive and require additional steps unlike conventional cements. ${ }^{39}$ The lower retentiveness of MN than RX may be explained by porosity and incomplete polymerization. The presence of residual acidic monomers near the adhesive interface may create weak areas and jeopardize adhesion. ${ }^{40}$

Previously, the luting space was not considered as a parameter for implant-retained metal-based restorations; now, it is widely accepted as a factor affecting cement durability and thus retention of such restorations. ${ }^{19}$ In a review, Tylor et al. ${ }^{3}$ stated that cement-retained implant superstructures may be completely passive because of the 25-30 $\mu \mathrm{m}$ space provided for the cement, a concept used in traditional fixed prosthodontics. Ebert et al. ${ }^{41}$ found that increase in the luting space from 30 to $60 \mu \mathrm{m}$ has a detrimental effect on cement durability and is problematic when resin cements are chosen. Wu and Wilson ${ }^{19}$ also reported that for optimal seating, the luting space must be larger than $30 \mu \mathrm{m}$. In most studies, the luting space ranged from 20 to $40 \mu \mathrm{m} 8^{8,12,13,33,41}$ These values were chosen in the present study because a cement film thickness of 20 to $40 \mu \mathrm{m}$ is generally considered optimal for complete seating of a restoration. ${ }^{24-26}$ The finding of improved retentiveness of the cements with the increased luting space of $40 \mu \mathrm{m}$ may be explained by the fact that cement film thickness, viscosity, and cohesive strength are related to size or shape of filler particles and affect retentiveness and retrievability.

Thermocycling simulates thermal changes in the oral cavity. ${ }^{42}$ It has been used for evaluating retentiveness of luting agents for metal components ${ }^{13}$, bond strengths of luting agents to an implant system ${ }^{43}$ and microleakage associated with luting agents. ${ }^{44}$ GaRey et al. ${ }^{45}$ found that thermocycling has minimal effect on retentiveness of resin cements. This finding may be attributed to the low solubility of resin cements compared with other luting agents. 46 Squier et al. ${ }^{13}$ thermocycled specimens between $5.1^{\circ} \mathrm{C}$ and $56.1^{\circ} \mathrm{C}$ for $24 \mathrm{~h}$ before tensile testing and found that zinc polycarboxylate was the most retentive cement while glass ionomer and eugenol-free zinc oxide had similar retentiveness. The results are similar to those the present study. However, no specimens without thermocycling were tested, so the effect of thermocycling on retentiveness could not be examined. Future studies need to determine the effect of thermocycling on retentiveness of different cements.

The fabrication of implant-supported restorations involves many clinical and laboratory procedures requiring a high degree of precision. Small errors can occur at each stage of fabrication and contribute to positional distortion of the prosthesis relative to the implant. ${ }^{7}$ In most previous studies of the retrievability of cementretained implant-supported crowns, standard fabrication techniques for metal superstructures were used. These techniques may give misleading results because distortions are possible at any stage. . $^{7,8,12,33,47-52}$ For standardization of copings, some authors preferred to use standard burnout caps fabricated by the implant manufacturer. . $^{8,13,15,33,47,51}$ However, investing and casting procedures probably contribute similarly to distortion. Furthermore, the luting space needed for passive fit with burnout caps is not always known. To guarantee standardization of copings, the $\mathrm{CAD} / \mathrm{CAM}$ technique was used to fabricate specimens in this study. Nonetheless, each abutment-coping pair was used only once, avoiding the possibility of surface contamination 
due to casting misfit.

A standardized protocol was followed at every stage; however, some limitations exist, such as inability to simulate the oral environment accurately and the specific physical conditions imposed. The pullout test design represented special clinical situations only. Slow-acting dislodging forces may occur with sticky food bolus intraorally. Given the limitations, no particular cement can be recommended for luting metal alloys on titanium abutments. The perfect luting agent for implant-supported restorations should offer clinicians the opportunity to vary the level of retentiveness depending on the clinical situation. In some cases, retrievability is indicated, so the luting agent should be easily and completely removable from the abutment or restoration surface. Further clinical studies are needed to confirm these results by comparing a variety of cements, varying abutment properties, evaluating multi-unit prostheses, and imitating the oral environment with improved methods.

\section{CONCLUSIONS}

In conclusion, both the luting agent and the luting space may affect retention of DMLS-fabricated implant-supported crowns. Increasing the luting space to $40 \mu \mathrm{m}$ may improve retention when higherstrength cements are used. The findings serve as an arbitrary guide to appropriate cement selection for enhanced retention of such restorations.

\section{Conflict of interest}

Ozgun Yusuf Ozyilmaz, Ceyda Akin and Mujde Sevimay declare that they have no conflict of interests.

Ethical approval: This article does not contain any studies with human participants or animals performed by any of the authors. 


\section{REFERENCES}

1. Hebel KS, Gajjar RC. Cement-retained versus screw-retained implant restorations: achieving optimal occlusion and esthetics in implant dentistry. J Prosthet Dent 1997; 77: 28-35.

2. Chee W, Felton DA, Johnson PF, Sullivan DY. Cemented versus screw-retained implant prostheses: which is beter? Int J Oral Maxillofac Implants 1999;14: 137-141.

3. Taylor TD, Agar JR, Vogiatzi T. Implant prosthodontics: current perspective and future directions. Int J Oral Maxillofac Implants. 2000; 15: 66-75.

4. Michalakis KX, Hirayama H, Garefis PD. Cementretained versus screw-retained implant restorations: a critical review. Int J Oral Maxillofac Implants 2003; 18: 719-28.

5. Vigolo P, Givani A, Majzoub Z, Cordioli G. Cemented versus screw-retained implant-supported single-tooth crowns: a 4-year prospective clinical study. Int J Oral Maxillofac Implants 2004; 19: 2605.

6. Weber HP, Sukotjo C. Does the type of implant prosthesis affect outcomes in the partially edentulous patient ? Int J Oral Maxillofac Implants 2007; 22: 140-72.

7. Mehl C, Harder S, Wolfart M, Kern M Wolfart S. Retrievability of implant-retained crowns following cementation. Clin Oral Implants Res 2008; 19: 130411.

8. Santosa RE, Martin W, Morton D. Effects of a cementing technique in addition to luting agent on the uniaxial retention force of a single-tooth implantsupported restoration: an in vitro study. Int $\mathrm{J}$ Oral Maxillofac Implants 2010; 25: 3145-52.

9. Assenza B, Scarano A, Leghissa G, Carusi G, Thams U, Roman FS et al. Screw-vs cementimplant-retained restorations: an experimental study in the beagle. Part 1. Screw and abutment loosening. J Oral Implantol 2005; 31: 242-46.

10.Torrado E, Ercoli C, Al Mardini M, Graser GN, Tallents $\mathrm{RH}$, Cordaro L. A comparison of the porcelain fracture resistance of screw-retained and cement-retained implant-supported metal-ceramic crowns. J Prosthet Dent 2004; 91: 532-37.

11.Edelhoff D, Ozcan M. To what extent does the longevity of fixed dental prostheses depend on the function of the cement? Working Group 4 materials: cementation. Clin Oral Implants Res 2007; 18: 193204.

12.Pan YH, Ramp LC, Lin CK, Liu PR. Comparison of 7 luting protocols and their effect on the retention and marginal leakage of a cement retained dental implant restoration. Int $\mathrm{J}$ Oral Maxillofac 2006; 21: 587-92.
13.Squier RS, Agar JR, Duncan JP, Taylor TD. Retentiveness of dental cements used with metallic implant components. Int $\mathrm{J}$ Oral Maxillofac Implants2001;16: 793-98.

14.Bernal G, Okamura M, Muñoz CA. The effects of abutment taper, length and cement type on resistance to dislodgement of cement-retained, implant-supported restorations. J Prosthodont 2003; 12: 111-15.

15. Heintze SD. Crown pull-off test (crown retention test) to evaluate the bonding effectiveness of luting agents. Dent Mater 2010; 26: 193-206.

16. Wolfart M, Wolfart S, Kern M. Retention forces and seating discrepancies of implant retained castings after cementation. Int $\mathrm{J}$ Oral Maxillofac Implants 2006; 21: 519-25.

17. Kokubo $Y$, Kano T, Tsumita M, Sakurai S, Itayama A, Fukushima S. Retention of zirconia copings on zirconia implant abutments cemented with provisional luting agents. J Oral Rehabil 2010; 37: 48-53.

18. Psillakis JJ, McAlarney ME, Wright RF, Urquiola $J$, MacDonald DE. Effect of evaporation and mixing technique on die spacer thickness: a pilot study. J Prosthet Dent 2001; 85: 82-7.

19. Wu JC, Wilson PR. Optimal cement space for resin luting cements. Int J Prosthodont 1994; 7: 209-15.

20.Phillips R. Skinner's Science of Dental Materials 1991;44-50.

21.Grajower R, Lewinstein I. A mathematical treatise on the fit of crown castings. J Prosthet Dent 1983; 49: 663-74.

22.Passon C, Lambert RH, Lambert RL, Newman $\mathrm{S}$. The effect of multiple layers of die-spacer on crown retention. Oper Dent 1992; 17: 42-9.

23. Campbell SD. Comparison of conventional paint-on die spacers and those used with the all-ceramic restorations. J Prosthet Dent 1990; 63: 151-55.

24.Emtiaz S, Goldstein G. Effect of die spacers on precementation space of complete coverage restorations. Int J Prosthodont 1997;10:131-35.

25. Fusayama $\mathrm{T}$, Ide $\mathrm{K}$, Hosoda $\mathrm{H}$. Relief of resistance of cement of full cast crowns. J Prosthet Dent 1964; 14: 95-106.

26. Webb LE, Murray HV, Holland GA Taylor DF. Effect of preparation, relief and flow channels on seating full coverage castings during cementation. J Prosthet Dent 1983; 49: 777-80.

27. Ucar Y, Akova T, Akyıl MS, Brantley WA. Internal fit evaluation of crowns prepared using a new dental crown fabrication technique: lasersintered Co-Cr crowns. J Prosthet Dent 2009; 102: 253-59. 
28.Akova T, Ucar Y, Tukay A, Balkaya MC, Brantley WA. Comparison of the bond strength of lasersintered and cast base metal dental alloys to porcelain. Dent Mater 2008; 24: 1400-4.

29. Quante K, Ludwig K, Kern M. Marginal and internal fit of metal-ceramic crowns fabricated with a new laser melting technology. Dent Mater 2008; 24: 1311-15.

30.Örtorp A, Jönsson D, Mouhsen A, Vult von Steyern $P$. The fit of cobalt-chromium three-unit fixed dental prostheses fabricated with four different techniques: a comparative in vitro study. Dent Mater 2011; 27: 356-63.

31.Abbo B, Razzoog ME, Vivas J, Sierraalta M. Resistance to dislodgement of zirconia copings cemented onto titanium abutments of different heights. J Prosthet Dent 2008; 99: 25-9.

32. Strub JR, Rekow ED, Witkowski S. Computeraided design and fabrication of dental restorations: current systems and future possibilities. J Am Dent Assoc 2006;137:1289-96.

33. Mansour A, Ercoli C, Graser G, Tallents R, Moss M. Comparative evaluation of casting retention using ITI solid abutment with six cements. Clin Oral Impl Res 2002; 13: 343-8.

34.Darvell BW. Materials Science for dentistry. 2002;7th edition, (ISBN 962-85391-5-9).

35. Schissel C, Schaefer L, Winter C, Fuerst J, Rosentritt M, Zeman F, Behr M. Factors determining the retentiveness of luting agents used with metal-and ceramic-based implant components. Clin Oral Invest 2013; 17: 1179-90.

36. Hotz P, McLean JW, Sced I, Wilson AD. The bonding of glass ionomer cements to metal and tooth substrates. Br Dent J 1977; 142: 41-7.

37.Annusavice KJ. Science of dental materials 2006;10th edition, St Louis, Saunders, 471-5.

38. Monticelli F, Grandini S, Goracci C, Ferrari M. Clinical behavior of translucent-fiber posts: a 2year prospective study. Int J Prosthodont 2003; 16: 593-6.

39.Schwartz RS, Robbins JW. Placement and restoration of endodontically treated teeth: Aliterature review. J Endod 2004; 30: 289-301.

40.Monticelli F, Osorio R, Mazzitelli C, Ferrari M, Toledano M. Limited decalcification/diffusion of self-adhesive cements into dentin. J Dent Res 2008; 87: 974-9.

41. Ebert A, Hedderich J, Kern M. Retention of zirconia ceramic copings bonded to titanium abutments. Int J Oral Maxillofac Implants 2007; 22: 921-7.

42. Gale MS, Darvell BW. Thermal cycling procedures for laboratory testing of dental restorations. J Dent 1999; 27: 89-9.

43. Clayton GH, Driscoll CF, Hondrum SO. The effect of luting agents on the retention and marginal adaptation of the CeraOne implant system. Int $\mathrm{J}$ Oral Maxillofac Implants 1997; 12: 660-5.
44. White SN, Sorensen JA, Kang SK, Caputo AA. Microleakage of new crown and fixed partial denture luting agents. J Prosthet Dent 1992; 67: 156-161.

45. GaRey DJ, Tjan AH, James RA, Caputo AA. Effects of thermocycling, load-cycling, and blood contamination on cemented implant abutments. J Prosthet Dent 1994; 71: 124-132.

46. O'Brien WJ. Dental cements. In: O'Brien WJ, ed. Dental Materials: Properties and Selection. Chicago: Quintessence Publishing Co 1989: 538-542.

47.Akça K, Iplikcioglu H, Cehreli MC. Comparison of uniaxial resistance forces of cements used with implant-supported crowns. Int J Oral Maxillofac Implants 2002; 17: 536-42.

48. Pan YH, Ramp LC, Lin CK, Liu PR. Retention and leakage of implant-supported restorations luted with provisional camant: a pilot study. J Oral Rehabil 2007; 34: 206-12.

49. Razzoog ME, Lang LA, McAnsrew KS. AllCeram crowns for single replacement implant abutments. J Prosthet Dent 1997; 78: 486-9.

50. OliveraAB, Saito $T$. The effect of die spacer on retention and fitting of complete cast crowns. J Prosthodont 2006; 15: 243-9.

51.Kim Y, Yamashita J, Shotwell JL, Chong KH, Wang HL. The comparison of provisional luting agents and abutment surface roughnes on the retention of provisional implant-supported crowns. J Prosthet Dent 2006; 95: 450-5.

52. Michalakis K, Pissiotis AL, Kang K, Hirayama $H$, Garefis PD, Petridis $H$. The effect of thermal cycling and air abrasion on cement failure loads of 4 provisional luting agents used fort he cementation of implant-supported fixed partial dentures. Int J Oral Maxillofac Implants 2007; 22: 569-74.

\section{Yazışma Adresi:}

Yrd.Doç.Dr. Özgün Yusuf ÖZYILMAZ

İstanbul Medipol Üniversitesi

Diş Hekimliği Fakültesi

Protetik Diş Tedavisi AD

Bağcılar, İstanbul, Türkiye

Gsm : +90 5322800532

Tel : +90 2124607651

Faks : +90 2124607070

E-mail: oyozyilmaz@medipol.edu.tr 